\title{
1. EU citizenship and civil rights: an underexplored nexus
}

\section{Henri de Waele and Marie-Pierre Granger}

\section{CIVIL RIGHTS AND EU CITIZENSHIP}

Civil rights are core citizenship rights. The term itself is in fact derived from the Latin ius civis, referring to 'the rights of the citizen'. Civil rights form the basis that supports the exercise of other rights, be they political, economic or social. Therefore, one cannot engage in an examination or appraisal of the concept and practice of EU citizenship, and of the barriers which actually or potentially hinder its development and exercise, without a thorough investigation of the civil rights that are associated with it. For that reason, due attention was given to this thematic within the interdisciplinary research project 'bEUcitizen' that gave rise to a whole series of books, of which the present volume constitutes merely one tome.

An enquiry into the civil rights attached to EU citizenship is complicated by the multilevel and multi-layered nature of the concept. First, as a status, EU citizenship is dependent on national citizenship, complementing it without replacing it. ${ }^{1}$ Second, it interacts, overlaps and competes with national citizenship, as well as with other formal and informal community memberships across Europe.

As such, EU citizenship does not directly confer civil rights beyond a limited right to move and reside in other Member States. However, alongside a growing fundamental rights acquis guaranteed at the supranational level, the concept has helped to enhance the access to, and the exercise of, a range of civil rights across the Member States. Moreover, this dynamic has produced some significant transformative effects on

\footnotetext{
1 Art 9 of the Treaty establishing the European Union; Art 20 of the Treaty on the Functioning of the European Union (TEU).
} 
citizenship rules and practices across Europe - producing 'an amplified bundle of options' indeed. ${ }^{2}$

The encounter between European integration and civil rights has often been portrayed as a collision site. The European (Economic) Communities that eventually evolved into the European Union, with their strong market-building project, the panoply of common policies in areas such as agriculture, competition, commercial or transport matters, increased coordination and cooperation across a range of domains including nowadays justice and home affairs, regularly came into conflict with nationally protected civil rights, such as the right to property, freedom of expression, freedom of assembly, the right to privacy and family life, the right to a fair trial, due process guarantees, and so on. As the notion of Union citizenship extended the right to move and reside across the (ever expanding) EU territory, from economically active (market) citizens to other categories of Member State nationals, as well as certain categories of third-country nationals (for example, family members, long-term residents), it enhanced individual spatial and migratory freedoms in Europe. ${ }^{3}$ Meanwhile, the EU is also steadily developing a legislative civil rights acquis. It has for instance made positive and distinctive, conceptual and practical contributions in the sphere of equality, with a range of measures against discrimination based on nationality, gender, sexual orientation, race, disability or age. Over the last two decades, the Union legislator has also fleshed out the modern version of the right to privacy, in particular the right to protection of personal data. In recent years, aiming to foster and maintain the mutual trust necessary to sustain police and judicial cooperation in civil matters, and even more so in criminal matters, the Union institutions have adopted measures guaranteeing respect for minimum standards of protection of accused persons and victims in criminal proceedings. Moreover, EU membership requires that the countries concerned uphold values common to them, which include respect for human rights. ${ }^{4}$

The case law of the Court of Justice of the European Union (CJEU) has long recognised general principles of Union law for the protection of fundamental rights, which in turn should guarantee respect for important civil rights by the various EU institutions and Member States when

2 Ulrich K Preuss, 'Problems of a Concept of European Citizenship' (1995) 1 ELJ 267.

3 Loïc Azoulai, 'Transfiguring European Citizenship: From Member State Territory to Union Territory' in Dimitry Kochenov (ed), EU Citizenship and Federalism: The Role of Rights (CUP 2017) 178.

4 See Art 2, 7 and 49 TEU. 
acting within the scope of EU law. The collection has more recently been codified and complemented in the EU Charter of Fundamental Rights (CFR), which affords protection to an even wider spectrum, and must be respected by the Union institutions and Member States when implementing Union law. ${ }^{5}$ Taken as a broad concept, which involves membership of a community of values rather than the thin 'complementary status' mentioned in the Treaties, EU citizenship offers new opportunities for the protection of civil rights in areas which are subject to European regulation $^{6}$ - but also, in some circumstances, in matters which have largely remained within national competences. ${ }^{7}$ When their situation falls within the scope of EU law, Union citizens and occasionally also other residents can invoke the (sometimes) higher supranational standards of civil rights' protection - for example, the right to respect for private and family life - when and where national legal systems fall short. ${ }^{8}$ In doing so, claimants can in principle rely on effective national remedies, and call upon the Union institutions to intervene (through, for instance, infringement actions by the European Commission, or preliminary rulings by the CJEU).

At the same time, in this broad sense EU citizenship also raises new challenges, as actions and instruments rooted in the supranational sphere of governance might themselves turn out to pose threats to civil rights. For instance, the rigid austerity measures that were adopted during the crisis of the Eurozone since 2008 may well have emptied of purpose the freedom of assembly and right to protest of citizens of Member States placed under EU supervision and strict conditionality regimes, alongside denting the protection of their right to property. ${ }^{9}$ Cooperation mechanisms such as the European Arrest Warrant can also place under considerable strain the right to a fair trial of those accused of crimes, as

5 See Art 51 CFR.

6 Marie-Pierre Granger, 'The Protection of Civil Rights and Liberties and the Transformation of Union Citizenship' in Sandra Seubert et al (eds), Moving Beyond Barriers: Prospects for EU Citizenship (Edward Elgar 2018) 178.

7 For a bold extrapolation, multiplying the number of circumstances where this would be possible, see Armin von Bogdandy et al, 'Reverse Solange Protecting the Essence of Fundamental Rights Against EU Member States' (2012) 49 CMLRev 489.

8 Marie-Pierre Granger, 'Federalization Through Rights in the EU: A Legal Opportunities Approach' (forthcoming).

9 cf Anastasia Poulou, 'Financial Assistance Conditionality and Human Rights Protection: What is the Role of the EU Charter of Fundamental Rights?' (2017) 54 CMLRev 991. 
they are being chased and mopped up all too easily across borders. ${ }^{10} \mathrm{EU}$ anti-terrorism measures, in se driven by perfectly valid security concerns, have led to sometimes wide-ranging intrusion into citizens' privacy, and severe restrictions to their freedom of movement. ${ }^{11}$ Correspondingly, the nexus between EU citizenship and civil rights is definitely not all rosy, but displays darker sides as well.

Much has been written already on the past, present and future of EU citizenship and the development and scope of protection of fundamental rights in the EU, as well as on the ties between EU citizenship and human rights. ${ }^{12}$ The role of distinct civil rights in the conceptual development and practice of EU citizenship, and the implications of that concept on civil rights protection, have nonetheless received less explicit and focused attention. Most studies emphasise that Union citizenship ultimately remains rooted in market integration, and stress the central part played by free movement as an 'economic' freedom in its development. However, the specific role played by civil rights in the elaboration of a new form of supranational citizenship, and their importance for its future evolution, has not been explored in full. This is all the more surprising since in domestic contexts across the world, not least within Europe itself, fights for civil rights often constituted defining moments in the construction of national citizenship and identity (consider, for example, the French Revolution, or the US civil rights movement). Evidently, the European Union has not yet matured into a political community that is comparable to that of a state - and perhaps it never will, and never should. Nevertheless, we cannot regard this as a justification for ignoring how the protection of civil rights already impacts the development of EU citizenship - and how it should perhaps influence that development further.

10 See, for example, Anneli Albi, 'The European Arrest Warrant, Constitutional Rights and the Changing Legal Thinking: Values Once Recognised Lost in Transition to the EU Level?' in Maria Fletcher, Ester Herlin-Karnell and Claudio Matera (eds), The European Union as an Area of Freedom, Security and Justice (Routledge 2017) 137.

11 See, for example, Sara Poli, 'The EU Anti-Terrorism Policy in its External AFSJ Dimension' in Maria Fletcher, Ester Herlin-Karnell and Claudio Matera (eds), The European Union as an Area of Freedom, Security and Justice (Routledge 2017) 389.

12 Inter alia Kochenov (n 3); Von Bogdandy et al (n 7); Henri de Waele, 'EU Citizenship: Revisiting its Meaning, Place and Potential' (2010) 12 EJML 319; Sara Iglesias Sánchez, 'Fundamental Rights and Citizenship of the Union at a Crossroads: A Promising Alliance or a Dangerous Liaison?' 20 (2014) ELJ 464. 
Constitutional scholars interested in civil rights tend to approach the issue from a comparative constitutional rights perspective. International human rights lawyers usually look at the role of international instruments, including the ECHR, in ensuring minimum protection for civil rights. EU lawyers mostly stress the Union's share in the development of equality norms, or the free movement of persons. In contrast, the current volume offers a different and original perspective, first of all aiming to highlight the relevance of EU citizenship for the protection of civil rights across the various levels and layers where it has made its presence felt. In addition, it seeks to explore the manner in which the protection of civil rights in Europe helps (or urges to) redefine citizenship beyond the state. Last but not least, the book should assist in pinpointing barriers to the exercise of their civil rights by EU citizens, especially at the national level, so that they can be tackled and gradually eradicated. As evinced by its subtitle, the approach hereby adheres to three main 'nodes', highlighting challenges that originate from respectively the European, the national and the private sphere. In alternation, each of the chapters places emphasis on one or more of these nodes.

\section{LEAD QUESTIONS AND BOOK STRUCTURE}

The inquiries undertaken in this volume proceed from a selection of lead questions that either explicitly or implicitly permeate the different contributions. What is the impact of Union citizenship, and European integration more broadly, on the protection of civil rights in the EU? To what extent does European integration, and EU membership in particular, pose a threat to core civil rights? Does EU citizenship, understood as membership of community of values, make a significant contribution to the definition and effective realisation of civil rights in the EU? How marked is the difference in this regard between situations that fall under the scope of application of EU law, and situations that do not? What obstacles do EU citizens encounter when they seek to exercise their civil rights? Are there specific legal hurdles, such as differing/competing standards, confusion on the scope of application of EU civil right protection, or a shortage of effective remedies? Do EU citizens face serious administrative hurdles when they seek to exercise their civil rights? Are they confronted with societal apathy, pressure or hostility, which leads them to forfeit those rights? Does the EU sufficiently support its citizens who fight for their civil rights?

Judging from the preliminary research that was undertaken within the designated work package of the bEUcitizen project, obstacles to the 
effective exercise of civil rights by Union citizens seem to flow from the determination of legal remedies within given jurisdictions, institutional contexts at EU and national levels, the availability of judicial and non-judicial mechanisms, peculiarities of administrative structures, linguistic aspects, and societal pressures or inhibitions. In what follows, these aspects are canvassed in a horizontal or transversal manner, underscoring the national, European or private dimensions of the barriers - thus directly or indirectly linking up to the aforementioned questions.

The book comprises two parts. The first focuses on the general frameworks, surveying the actual or potential role of domestic and supranational bodies (Chapter 2), with specific attention for the position of private parties (Chapter 3) and the role played by civil society organisations (Chapter 4). The second part offers a dissection of the panoply of civil rights that are, might or should be connected to EU citizenship. It starts with a discussion of the 'right to have rights' and the challenges posed by the reliance of EU citizenship on the nationality of a member state (Chapter 5). It includes an exploration of the right to free movement, not as an economic right associated with market integration, but as the core civil right of EU citizens (Chapter 7). On a similar note, with non-discrimination having been a hallmark of the integration project since its inception, and bearing in mind that in all citizenship settings equality between citizens is an essential feature of citizenship, particular attention is paid to the extensive right to equal treatment under EU law (Chapter 6). A relatively novel right, the right to personal data protection, is also examined here, as it has grown to occupy a prominent position in EU law and policy (Chapter 11). Traditional boundaries are pushed further still, with a study on the impact that Union citizenship has on life events, and especially concomitant rights such as those to marriage, filiation and family life, which are affected ever more frequently in a context of increased mobility in the EU (Chapter 8). The classic freedom of expression, which has been so seminal in other jurisdictions like the USA, is placed in a different key. Having received more oblique attention in the study of the activities of civil society organisations, in the second part of the book it is addressed in the context of the media, with a specific focus on the freedom of citizen-journalists (Chapter 10).

Any undertaking of this kind, in particular when framed around a specific and predefined research project, has its limitations, and presupposes a preliminary delineation. Consequently, readers may be puzzled by the marked absence of civil rights that have traditionally occupied a central position in citizenship debates in national settings, which are likely to play a growing role in the future development of EU citizenship. The prime suspect here is the freedom of religion. In the EU 
context, that right is mainly addressed in a tangential fashion, through the prism of non-discrimination and respect for diversity, ${ }^{13}$ rather than directly as a core civil right and constitutive element of EU citizenship. ${ }^{14}$ The freedom of assembly should also have featured, one may argue, considering the ever more vocal pro- and anti-Europe protests, as well as the increasing fetters placed on civil society. The freedom of association, providing the framework for civil society organizations to promote and protect citizens' rights, would deserve a similarly central place, especially at a time when it is placed under ever greater strain in various EU countries. ${ }^{15}$ Rather than pointing to a weakness of the book, we argue instead that these absences highlight the relevance of further inquiries into the role of specific civil rights in the development of EU citizenship as a legal concept, but also as a social practice.

In terms of utility, the contributions contained in this volume should assist in identifying barriers to the exercise of EU citizenship rights of varying types and sizes. In contrast to the design of the original research project, these barriers are not addressed one by one here, depending on their nature (legal, administrative, practical, linguistic, and so on). Such an approach, transferred to a book format, would have produced a staccato, inaccessible and highly unattractive piece. The actual approach that has been preferred is one of enveloping movements, whereby authors depart from a sectoral or thematic plane, and zero in more gradually. It is true that in this set-up, the barriers that are in need of being exposed do not receive undivided attention, and do not play a starring role by themselves. Yet they are not pushed to the background either, but structurally - and arguably more effectively - woven into the larger picture. The contextual approach contributes to elucidating the factors obstructing the exercise of the civil rights attached to EU citizenship as

13 Compare Case C-157/15 Samira Achbita and Centrum voor gelijkheid van kansen en voor racismebestrijding $v$ G4S Secure Solutions NV, ECLI:EU: C:2017:203 and Case C-188/15 Asma Bougnaoui and Association de défense des droits de l'homme v Micropole SA, ECLI:EU:C:2017:204.

14 Contrast Joseph Weiler's meditation on the Christian ethical patrimony as a viable basis for integration, Un' Europa cristiana. Un saggio esplorativo (Biblioteca Rizzoli 2003).

15 EU Fundamental Rights Agency, 'Challenges Facing Civil Society Organisations Working on Human Rights in the EU' (Luxembourg, 2017) <http://fra. europa.eu/en/publication/2018/challenges-facing-civil-society-orgs-human-rightseu> accessed 26 February 2018. 
well as the underlying causes. The resulting kaleidoscopic view offers a richness and breadth that an assessment of isolated phenomena is bound to lack.

\section{THE CONTRIBUTIONS AT A GLANCE}

In the second chapter, John Morijn analyses the post-Lisbon application of the Charter of Fundamental Rights by the Union's political institutions, as well as the Fundamental Rights Agency (FRA) at the stage of developing EU legislation and policy. While the activities of each of these players are usually studied individually, his contribution purposely takes an integrated approach to highlight as important the distinct activities of each, as well as the resulting interaction in civil rights protection that is emerging at the political and the internal policy level. Focusing first on the systematic measures that have been put in place to check Charter compliance, Morijn finds that although these instruments appear useful in terms of design, their use may be subject to improvement and, possibly, intensification. He argues that these checks are a logical consequence of the Charter's binding nature (rather than a constitutional sea change), and that no additional compliance tools are needed. Turning to general and specific civil rights protection measures of the political institutions and the FRA in the second part of the contribution, Morijn argues that there exists a sense of overlapping efforts by the Commission and the Agency specifically. The political institutions increasingly refer to each other's work however, and initiate actions based on each other's endorsements. Therefore, a clear trend of an inter-institutional civil rights dialogue between the various actors is discernible - testifying of a hesitant realisation that it takes three to tango. The author therefore ventures to conclude that the groundwork for promoting and upholding the Charter's civil rights is in place, but that the onus is also on those who want to promote and uphold it more effectively.

In the third chapter, Sybe de Vries explores the potential and limits for enforcing civil rights in Member States in a horizontal fashion, at the level of the ECHR and at the EU level, with a specific focus on Union law and the Charter of Fundamental Rights. He especially zooms in on the hurdles that citizens encounter in relying on civil rights norms in a horizontal setting vis-à-vis other individuals, and on the question of how EU law and EU civil rights can be secured in such contexts. After shedding light on the occasionally enigmatic concept of horizontal direct 
effect, de Vries sketches the various pathways that may lead to successful enforcement of civil rights in private settings. Pursuant to the difficulties that are noted here, he tables a number of suggestions to promote and upgrade the (level of) protection in the private sphere.

The fourth chapter, authored by Javier González Vega, discusses the role played by civil society. It first takes into consideration its real and/or presumed involvement in global, EU and national structures and processes, paying attention to the identification of the key actors and their requisite legitimacy. Next, the normative framework related to civil society actors is examined through a multilevel analysis, focusing on EU tools of participatory democracy that are deemed relevant to standardsetting in civil rights, with special regard for the European Citizens' Initiative. Hereafter, the author provides a picture of the civil society organisations involved in the protection of civil rights in Member States across the EU, describing the methods through which they can influence legislation, and their main strategies to set up and enforce those rights. He concludes by indicating a number of gaps and shortcomings that ostensibly restrain their performance, arguing that these can be overcome only if they (are helped to) step up their game, improve their legal skills and technical abilities.

In the fifth chapter, inaugurating the second part of the book, Hanneke van Eijken and Pauline Phoa engage with what may be labelled 'the right to have rights' - the right to nationality that constitutes the gateway to EU citizenship. As they make clear, the latter status is additional to Member State nationality, and in principle Member States are exclusively competent to decide how persons can acquire and lose their nationality. Yet Union law has gradually placed outer limits on this competence. Phoa and Van Eijken start off by providing a general and comparative overview, highlighting commonalities and idiosyncrasies of the domestic systems. Next, they offer an analysis of developments in EU law (most notably, judgments from the Court of Justice), and comment on specific issues such as the withdrawal of nationality and the consequences of a possible Brexit. They come to the conclusion that the relationship between Member State nationality and Union citizenship can be looked at from two perspectives: on the one hand, as an example of the dynamic division of competences between the EU and its constituent parts, and on the other, from a more fundamental conceptual level. With regard to the latter, they deem the loss of EU citizenship to be particularly significant.

The sixth chapter, authored by Tomasz Dudek, purports to identify some of the barriers to the full enjoyment by EU citizens of the right to non-discrimination. His claim is that these at least in part result from the current structure of the Union's anti-discrimination framework. After an 
explanation of how 'equality' and 'non-discrimination' are understood in EU law, Dudek proceeds to dissect the framework and to discuss the (added) value of the substantive acquis in this field from the perspective of EU citizenship. He then moves to address three groups of barriers that are believed to limit the possibilities to enjoy this important civil right to non-discrimination. In so doing, he extensively and convincingly demonstrates that adaptation is in order, as the protection offered at the present day and time is uncertain and unhelpfully selective.

In the seventh chapter, Marie-Pierre Granger studies the relationship between the right to free movement, as it mutates from an economic into a civil right, and the development of Union citizenship. She first reflects on the relevance and role of free movement in the conception and evolution of the latter. Next, she reviews the legal cadre that organises the free movement of EU citizens and non-citizens across the Member States, to ascertain whether it grants all Union citizens equal opportunities in this regard, or whether it is more exclusive. The chapter then turns to its legal implementation and practical application in selected Member States, revealing that both in law and practice, free movement is neither a privilege nor a right for all citizens, questioning its centrality in the traditional narrative.

The eighth chapter, authored by Pilar Jiménez Blanco and Ángel Espiniella Menéndez, is dedicated to the right to family life, and the concomitant obstacles that may arise from intra-European mobility. The authors argue that protection of the right to family life implies the need to ensure the mobility of families within the EU. To this end, they first determine what the model of 'family' is in Union law, and then seek to establish how Union law facilitates its mobility. Thereafter, they consider existing limitations and constraints pursuant to the lack of harmonisation, and disparities between national legislation in the occurrence of three life events: filiation, acquisition and alteration of surnames, and marriage. The authors conclude by discussing five mechanisms that may mitigate the existing obstacles for (mobile) EU citizens, and the free movement of persons more generally.

In the ninth chapter, Silvia Adamo asks whether it is feasible to come up with a definition of access to justice that is particularly relevant for Union citizens. In order to answer this question, she links the right to the cases of data protection, civil litigation and criminal proceedings in the national practices of selected Member States, since these are all instances where disputes involving Union citizens may arise. In so doing, a variety of approaches with regard to access to justice emerge, depending on the national context of the country involved, the level of adherence to EU legal instruments, and the resources the various Member States allocate 
to the relevant implementation mechanisms. Support structures from private actors are also actively involved. The conclusions of this chapter point to the (easily underestimated) need to lift barriers for Union citizens in this field, and introduce supplementary means to access legal aid and services.

The tenth chapter, authored by Orsolya Salát, is devoted to the freedom of expression, surveying how it plays out in the conceptualisation and practice of citizen-journalism in the EU. Whilst supranational institutions have for some time engaged with the organisation and operation of media across the EU, so far they have not addressed the activities of citizenjournalists, despite the growing importance of blogs, social media and other online presence as alternative or complementary news providers. Salát investigates the way in which the phenomenon is regulated across Europe, reflecting on its value for the development of the concept of Union citizenship and an enhancement of civil rights protection. Without denying the potential harms caused by internet speech, her chapter relies on self-governance theories of freedom of speech to claim that citizen journalism might contribute to the formation of a truly European public sphere. Comparative empirical insights from national contexts, in particular from Hungary, illustrate the potentials and pitfalls of citizenjournalism, such as regulatory gaps, overlaps, inconsistencies and lack of funding. Substantive standards strongly diverge, aggravated by procedural uncertaintites at the EU level, and by the non-compliance of some Member States with minimum ECHR standards. The funding of citizen journalism proves increasingly problematic as well, due to pressure on civil society. To the mind of the author, EU institutions and Member States would do well to promote further legal harmonisation and financial stability of citizen-journalism. Her conclusions evidence that its rising attraction carries definite implications for the EU citizenship paradigm thereby intriguingly pitting a liberal against a republican notion.

In the eleventh and last substantive chapter, Marie-Pierre Granger and Kristina Irion survey the right to data protection, making the case that this is in fact the 'new posterchild' of EU citizenship in the digital era. They first portray the gradual building of the right to personal data protection in the EU, from its internal market origins to its current central position in the Union's constitutional order, and the extensive, recently reformed set of legislative measures. They then turn their attention to the 'builders' of this new right, exploring the role played by specific societal actors, including Union citizens themselves, in the development and enforcement of a strong protection for personal data in the EU. Thereafter, they review the current legal architecture of the right to protection of personal data, and discuss whether it could serve as a model for the 
future development of Union citizens, despite key challenges at the level of national implementation, and public and private compliance with EU rules.

The editors round off the book with a succinct, forward-looking epilogue that constitutes the twelfth and final chapter. Thereby, they offer a reply to the questions that functioned as drivers of the inquiries undertaken by the aforementioned authors. By juxtaposing salient findings related to the European, national and private sphere, the different nodes are neatly brought back together, allowing for the formulation of concluding thoughts on possible future trajectories. On that footing, some divergent potential scenarios are reflected upon, ultimately embracing unbounded mobility as the more likely basis for a further evolution of EU citizenship - culminating perhaps in a genuine European civil rights mo(ve)ment. 